\title{
Population ecology and shell chemistry of a phytal ostracode species (Loxoconcha matagordensis) in the Chesapeake Bay watershed
}

\author{
Cheryl D. Vann ${ }^{\mathrm{a}}$, Thomas M. Cronin ${ }^{\mathrm{a}, *}$, Gary S. Dwyer ${ }^{\mathrm{b}}$ \\ ${ }^{a}$ Department of the Interior, U.S. Geological Survey, 12201 Sunrise Valley Drive, National Center, MS 926A, Reston, VA 20192, United States \\ ${ }^{\mathrm{b}}$ Division of Earth and Ocean Sciences, Nicholas School of the Environment and Earth Sciences, Duke University, 103 Old Chemistry Building, \\ Durham, NC 27708, United States
}

Received 9 December 2003; received in revised form 16 June 2004; accepted 29 June 2004

\begin{abstract}
Population ecology and shell chemistry were studied in the phytal ostracode Loxoconcha matagordensis (Swain 1955) collected from Zostera marina seagrass beds in the Chesapeake Bay to provide seasonal constraints on shell secretion time for paleothermometry. Population density and age structure were defined by two main breeding cycles that occurred between 01 to 15 June and 02 to 16 August 2001. The time interval between breeding cycles was $\sim 2$ months and total juvenile standing crop increased almost three-fold between the first and second breeding cycles. Dark brown over-wintered adults comprised the majority of the population between March and April 2001, while newly secreted translucent adults were predominant between June and September. Seasonal shell $\mathrm{Mg} / \mathrm{Ca}$ and $\mathrm{Sr} / \mathrm{Ca}$ ratios were positively correlated with water temperature at both sites, with the strongest correlations occurring between June and September from newly secreted shells at Dameron Marsh. Old, dark brown shells contained $10 \%$ to $23 \%$ and $1 \%$ to $6 \%$ less $\mathrm{Mg} / \mathrm{Ca}$ and $\mathrm{Sr} / \mathrm{Ca}$, respectively, than new shells. Because a fossil assemblage of $L$. matagordensis will contain $\sim 30 \%$ old shells (dark-brown), these results suggest that fossil $\mathrm{Mg} / \mathrm{Ca}$ ratios yield an integrated late spring to summer temperature signal. Shell $\mathrm{Mg} / \mathrm{Ca}$ and $\mathrm{Sr} / \mathrm{Ca}$ ratios of specimens of L. matagordensis collected from living Zostera were positively correlated, suggesting that temperature may influence both elemental ratios. $\mathrm{Mg} /$ $\mathrm{Ca}$ and $\mathrm{Sr} / \mathrm{Ca}$ ratios of fossil shells of the related species Loxoconcha sp. A obtained from four sediment cores were also studied and exhibited a weaker correlation between the two elemental ratios.
\end{abstract}

(C) 2004 Elsevier B.V. All rights reserved.

Keywords: Ostracoda; Paleoclimatology; Ecology; Minor elements; Holocene; Seagrass

* Corresponding author. Tel.: +703 648 6363; fax: +7036486953.

E-mail address: tcronin@usgs.gov (T.M. Cronin). 


\section{Introduction}

The chemical composition of ostracode shells has become an important tool in paleoenvironmental reconstruction of both lake (Chivas et al., 1986; Xia et al., 1997; Wansard et al., 1998; Ito et al. 2003) and marine systems (Dwyer et al., 1995; Corrège and De Deckker, 1997). Ostracodes are microcrustaceans that have bivalve shells comprised of the mineral calcite $\left(\mathrm{CaCO}_{3}\right)$ and chitin. Unlike mollusks that exhibit accretionary growth, most ostracodes grow by molting their shells eight times during ontogeny. Following molting, calcification of the new shell occurs quickly, generally within a few hours (Turpen and Angell, 1971) to days (Chivas et al., 1983; Roca and Wansard, 1997), thus providing a chemical record representative of the environment in which it was formed.

Because ostracode shells are calcitic, magnesium and strontium can substitute for calcium in the calcite lattice. Several studies have shown that the rate at which $\mathrm{Mg}$ is incorporated into the shell depends primarily on water chemistry $(\mathrm{Mg} / \mathrm{Ca}$ ratio of the host water) and temperature (Chivas et al., 1983; Engstrom and Nelson, 1991; De Deckker et al., 1999). It has also been proposed that the primary factor regulating $\mathrm{Sr}$ incorporation is water chemistry, specifically, the $\mathrm{Sr} / \mathrm{Ca}$ ratio and salinity (Chivas et al., 1993). Several studies suggest, however, that the incorporation of $\mathrm{Mg}$ and $\mathrm{Sr}$ into the calcite lattice of some species is a function of more than just water chemistry and temperature (Xia et al., 1997; Wansard et al., 1998; Palacios-Fest and Dettman, 2001). For example, $\mathrm{Sr} / \mathrm{Ca}$ ratios of the ostracode Candona rawsoni, living in a hyposaline lake, exhibited a positive covariance with shell $\mathrm{Mg} / \mathrm{Ca}$ ratios indicating that $\mathrm{Sr}$ uptake increases with $\mathrm{Mg}$ content of the shell (Xia et al., 1997). In another study of lake ostracodes, Candona neglecta, C. marchica and C. candida exhibited high $\mathrm{Mg}$ shell contents even though they grew in water with low $\mathrm{Mg} / \mathrm{Ca}$ values $(\$ 2)$ (Wansard et al., 1998). Recently, it has been suggested that the elemental composition of the Cypridopsis vidua shell is primarily a function of ostracode biology and water temperature, with water chemistry playing a minor role (Palacios-Fest and Dettman, 2001).

The extent to which shell chemistry can be accurately applied to environmental reconstruction depends on an understanding of the chemical and biological mechanisms and ecological factors that govern shell secretion and chemical composition. Laboratory culturing studies have examined ostracode biology and ecology in relation to shell chemistry composition (Xia et al., 1997; De Deckker et al., 1999), but few studies have been conducted under natural field conditions. Frequent sampling in natural conditions is important for understanding the effects of seasonal climate variability on breeding cycle, molting, shell formation and general life history; effects that cannot be mimicked in artificially cultured environments.

This study expands the research of Cronin et al. (in press), which provides a discussion of Loxoconcha shell size, intra-shell $\mathrm{Mg} / \mathrm{Ca}$ variability, and preliminary shell chemistry for a $\mathrm{Mg} / \mathrm{Ca}$ : temperature calibration based on four Atlantic Ocean Loxoconcha species. In the current study, we investigated the population dynamics of the ostracode Loxoconcha matagordensis, with relation to shell chemistry composition over a 6-month period in the Chesapeake Bay. Loxoconcha matagordensis is a phytal species first described by Swain (1955) from San Antonio Bay, Texas. L. matagordensis tolerates a wide salinity range ( $\sim 15-30 \mathrm{ppt})$ and lives mainly on leaf blades of the seagrass Zostera marina found growing along the North Atlantic and Gulf coasts of North America. Biological factors such as breeding cycle, ontogeny, and the relationship between $Z$. marina and $L$. matagordensis population density were analyzed. In addition, the chemical composition of L. matagordensis shells ( $\mathrm{Mg} / \mathrm{Ca}$ and $\mathrm{Sr} / \mathrm{Ca}$ ratios) was compared with water temperature and salinity, and the relationship between $\mathrm{Mg} / \mathrm{Ca}$ and $\mathrm{Sr} / \mathrm{Ca}$ elemental ratios in a related species, Loxoconcha sp. A. occurring in sediment cores was evaluated.

\section{Materials and methods}

\subsection{Dameron marsh}

Dameron is a brackish marsh located between $37^{\circ} 46^{\prime} 30^{\prime \prime} \mathrm{N}$ and $37^{\circ} 47^{\prime} 30^{\prime \prime} \mathrm{N}$ and $76^{\circ} 17^{\prime} \mathrm{W}$ and $76^{\circ} 18^{\prime} \mathrm{W}$ that forms the southern peninsula shore of Ingram Bay, a tributary of the Chesapeake Bay (Fig. 1). The site has an abundance of both emergent and 


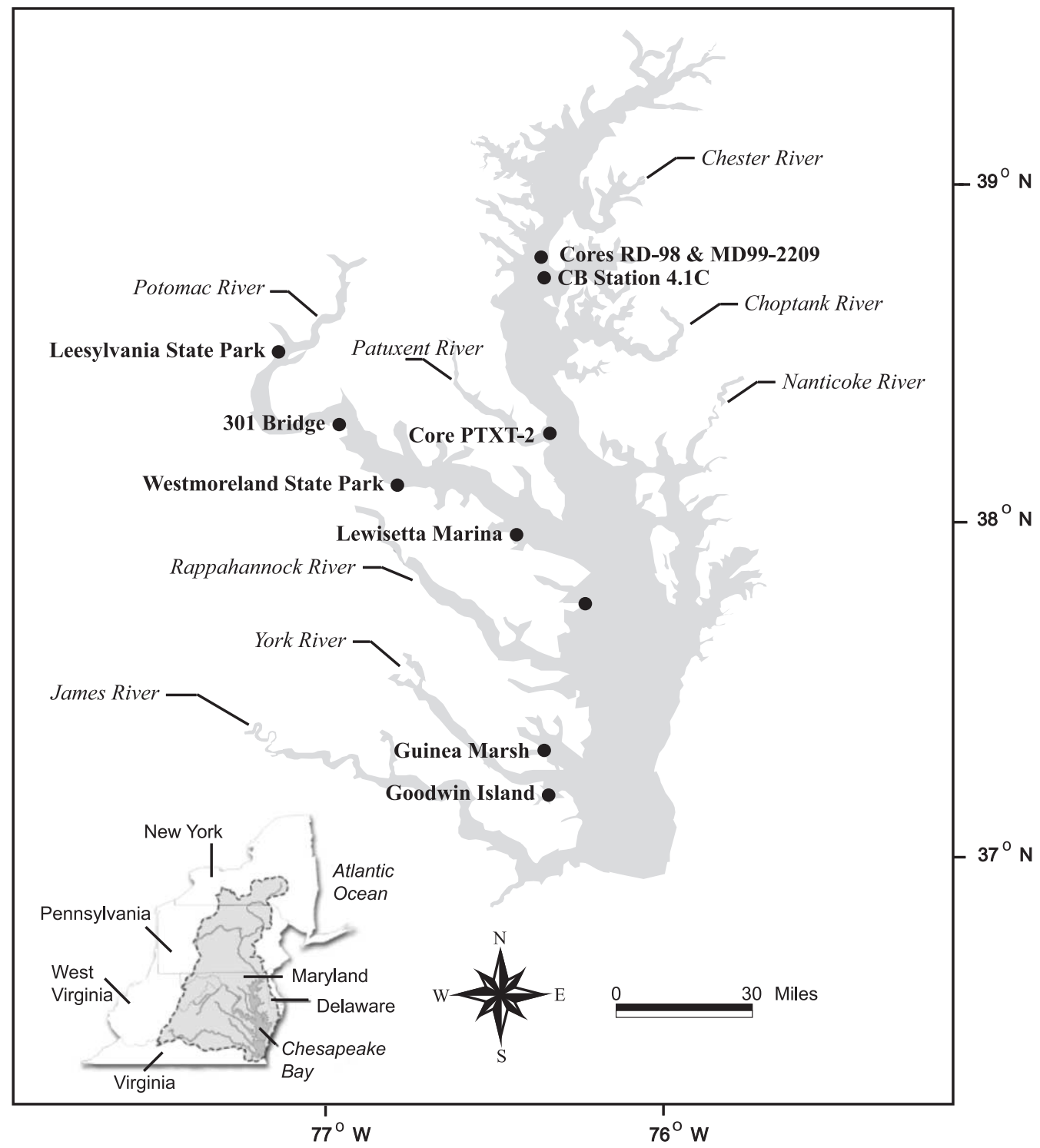

Fig. 1. Map of Chesapeake Bay showing the three study sites.

submerged aquatic vegetation that consists primarily of emergent Juncus roemerianus, Spartina sp., Myrica sp. and submerged Z. marina and Ruppia sp. Climatic conditions over the course of the 6-month experiment are presented in Table 1.

Two sub-sites were selected for this study. Site 1, $\left(37^{\circ} 47^{\prime} 4.3^{\prime \prime} \mathrm{N} ; 76^{\circ} 17^{\prime} 44.3^{\prime \prime} \mathrm{W}\right)$ is characterized by three $Z$. marina beds, each $<2.3 \mathrm{~m}^{2}$, located within 5.8 $\mathrm{m}$ of shore at a depth of $\sim 0.5 \mathrm{~m}$ with no other seagrass beds in close proximity. During the study period, water temperature was 7.8 to $30.3{ }^{\circ} \mathrm{C}$ and the salinity range was $13.5-17.9$ ppt. A thin layer $(<0.5 \mathrm{~cm})$ of peat was consistently present on the sediment surface, indicating a greater input of organic matter from the adjacent Spartina patens at this site than at Site 2. Site 2, $\left(37^{\circ} 47^{\prime} 8.9^{\prime \prime} \mathrm{N} ; 76^{\circ} 17^{\prime} 31.4^{\prime \prime} \mathrm{W}\right)$ located $\sim 0.5 \mathrm{~km}$ from Site 1 , is characterized by larger Z. marina beds, each $>3 \mathrm{~m}^{2}$, with many other beds in close proximity to our study beds. Zostera marina study beds were within 10 to $14 \mathrm{~m}$ of shore at a water depth of $\sim 1 \mathrm{~m}$. 
Table 1

Mean air temperature $\left({ }^{\circ} \mathrm{C}\right)$ and precipitation $(\mathrm{cm})$ for Virginia between March and August 2001 (Website: http://lwf.ncdc.noaa.gov)

\begin{tabular}{llllr}
\hline Date & Mean air temperature & Mean air temperature $\left({ }^{\circ} \mathrm{C}\right)$ & Mean Precipitation & Mean Precipitation $(\mathrm{cm})$ \\
\hline March 2001 & Below Normal & 5.4 & Above Normal & 11.4 \\
April 2001 & Above Normal & 13.7 & Much Below Normal & 4.1 \\
May 2001 & Normal & 17.1 & Above Normal & 12.6 \\
June 2001 & Normal & 21.9 & Above Normal & 11.9 \\
July 2001 & Much Below Normal & 22.2 & Above Normal & 12.9 \\
August 2001 & Above Normal & 23.8 & Normal & 9.6 \\
\hline
\end{tabular}

Water temperature and salinity ranges were consistent with those of Site 1, except on 03 March 2001, when water temperature was $7.1{ }^{\circ} \mathrm{C}$ and salinity was 18.3 ppt yielding a difference between the two sites of 0.7 ${ }^{\circ} \mathrm{C}$ and 0.4 ppt, respectively.

Thousands of $Z$. marina leaves were collected from both sites by hand twice per month between March and September 2001, and placed into plastic bags and kept on ice until processing. Five $Z$. marina leaf blades per collection date were randomly selected for height and width measurements. All Z. marina leaves were dried at $45{ }^{\circ} \mathrm{C}$ for 5 days and weighed for biomass determination. Water temperature and salinity were measured at the time of collection using a portable conductivity, salinity and temperature meter (YSI 30) with an accuracy of \pm 0.1 ${ }^{\circ} \mathrm{C}$ and $\pm 1 \%$, respectively.

Loxoconcha matagordensis specimens were isolated from $Z$. marina leaf blades by washing the leaves through a $63-\mu \mathrm{m}$ sieve at the USGS ostracode lab, Reston, VA. The contents of the sieve were placed in a filter paper funnel and oven-dried at 45 ${ }^{\circ} \mathrm{C}$. Ostracode carapaces that were alive at the time of collection and contained soft body parts, were picked from the dried sediment using a fine brush, placed on microfaunal slides and identified to the species level. Adult L. matagordensis specimens were categorized as translucent-clean or brown-dirty according to the terminology of Kamiya (1988), who showed that older adults accumulate organic debris on the exterior of their shells, leading to the browndirty appearance. This distinction allowed newly secreted shells to be differentiated from old, darkbrown shells.

Geochemical analyses (Section 2.4) were performed on individual $L$. matagordensis specimens from Dameron Marsh, Site 2 for each collection date between March and September 2001. Five adult female carapaces, 0.27 to $0.30 \mathrm{~mm}$ in length, were selected from each collection date (Dameron Marsh) for analysis. In addition, 20 carapaces, 10 old and 10 new, from the 01 and 15 June 2001, collections were analyzed in order to compare the chemical composition of old versus new specimens.

\subsection{York River}

The York River is a major tributary of the Chesapeake Bay with a watershed covering approximately 1.7 million acres of the Virginia coastal plain. Two sites at the mouth of the York River, Guinea Marsh (latitude $37^{\circ} 16^{\prime} \mathrm{N} ; 76^{\circ} 23^{\prime} \mathrm{W}$ ) and Goodwin Island (latitude $37^{\circ} 13^{\prime} \mathrm{N} ; 76^{\circ} 23^{\prime} \mathrm{W}$ ), were selected for geochemical analysis of L. matagordensis because of healthy $Z$. marina beds and more than a decade of water quality monitoring by the Virginia Institute of Marine Science (VIMS) (Moore and Berry-Niekirk, personal communication, 2002). Seasonal variations in water temperature and salinity ranged from 13 to $27.2{ }^{\circ} \mathrm{C}$ and 12.2 to $20.5 \mathrm{ppt}$, respectively, at both sites.

Zostera marina samples were collected monthly between March and September 2000, by the US Geological Survey, in cooperation with the Virginia Institute of Marine Science. A post-hole device was used to collect a composite sample of sediment and Z. marina in $\sim 1 \mathrm{~m}$ of water from both sites. After collection, Z. marina leaves were immediately separated from the sediment to minimize epiphytal and benthic ostracode species mixing, placed in separate sealed plastic bags in cooled containers, and shipped overnight to the USGS ostracode lab. Water temperature and salinity were measured at the time of collection.

Loxoconcha matagordensis specimens were isolated and picked from Z. marina samples following 
procedures used for Dameron Marsh samples. Five adult female carapaces of $L$. matagordensis, 0.27 to $0.30 \mathrm{~cm}$ in length, were selected for each collection date for individual shell geochemical analysis.

\subsection{Chesapeake Bay sediment cores}

Four sediment cores, RD-K-98, MD99-2209, PTXT-2-P-5 and PTMC-3, were taken in the Chesapeake Bay at $38^{\circ} 53.20^{\prime} \mathrm{N}$ and $76^{\circ} 23.50^{\prime} \mathrm{W}$; $38^{\circ} 19.58^{\prime} \mathrm{N}$ and $76^{\circ} 23.55^{\prime} \mathrm{W} ; 38^{\circ} 01.61^{\prime} \mathrm{N}$ and $76^{\circ} 13.19^{\prime} \mathrm{W}$, respectively (see Cronin et al., 2003 for core data and chronology). Cores RD-K-98 $(\sim 400 \mathrm{~cm})$ and MD99-2209 $(1720 \mathrm{~cm})$ were from the same location and the uppermost $800 \mathrm{~cm}$ of MD99-2209 were spliced together with the RD-K-98 record to provide the longest record of fossil Loxoconcha shells that dated back to $\sim 2200$ years before present. PTXT2-P-5 and PTMC-3 were shorter cores, total depths of 397 and $366 \mathrm{~cm}$, and contained fossil Loxoconcha sp. shells that dated back to 475 and 734 years before present, respectively.

Sediment core samples were taken at $2-\mathrm{cm}$ intervals and washed through a $63-\mu \mathrm{m}$ sieve at the USGS ostracode lab. The contents of the sieve were placed in a filter paper funnel and dried for 1 day at $45{ }^{\circ} \mathrm{C}$. In contrast to the shallow water seagrass habitat of L. matagordensis, these cores were taken in the deeper (11 to $>40 \mathrm{~m}$ ) main channel of Chesapeake Bay, which is inhabited by a related species of Loxoconcha, referred to here as Loxoconcha sp. A. Adult shells of Loxoconcha sp. A were picked from the dried sediment and placed on microfaunal slides prior to geochemical analyses. From each 2-cm interval, one to five fossil adult carapaces or valves of $L$. sp. A were selected for geochemical analysis.

\subsection{Geochemical analysis}

Geochemical analyses were performed on individual L. matagordensis specimens from either Guinea Marsh or Goodwin Island and Dameron Marsh, Site 2 for each collection date between March and September 2000 and 2001, respectively. Five replicate adult carapaces per collection date from both Dameron Marsh and York River sites and between one and five fossil adult carapaces or valves per 2-cm interval
(Chesapeake Bay sediment cores) were soaked in $100 \%$ Clorox ( $5 \%$ by volume sodium hypochlorite) for $24 \mathrm{~h}$ to remove organic matter. An additional 20 carapaces, 10 old and 10 new, from the June 1 and 15 Dameron Marsh collections were soaked for the old versus new trace element comparison. Carapaces were then rinsed four times with deionized water, with the final two rinses under gentle sonication. One valve per carapace was dissolved for $24 \mathrm{~h}$ in $3 \mathrm{ml}$ of $0.05 \mathrm{~N}$ nitric acid and analyzed for magnesium, calcium, strontium and sodium (not addressed in this paper) using a Spectrascan 7 direct current plasma (DCP) emission spectrometer at Duke University (Dwyer et al. 1995). Replicate analyses of samples and standards yielded an analytical precision of $\pm 3 \%$ and a limestone standard (Duke PE3) yielded a $\mathrm{Mg}$ / $\mathrm{Ca}$ reading of $8.40 \mathrm{mmol} / \mathrm{mol}$ and a $\mathrm{Sr} / \mathrm{Ca}$ reading of $7.82 \mathrm{mmol} / \mathrm{mol}$. The data presented in this paper are available at the following URL: http://geology. er.usgs.gov/eespteam/Atlantic/.

\section{Statistical analyses}

Linear regression analyses were performed to establish the relationship between water temperature and shell $\mathrm{Mg} / \mathrm{Ca}$ and $\mathrm{Sr} / \mathrm{Ca}$ ratios and Z. marina height. A paired $t$-test, confidence level $99 \%$, was used to compare $\mathrm{Mg} / \mathrm{Ca}$ and $\mathrm{Sr} / \mathrm{Ca}$ ratios of old and new shells.

\section{Results}

\subsection{Zostera marina growth cycle-Dameron Marsh}

Zostera marina leaf blades began emerging from underground rhizomes between February and March 2001, with average heights of 11.4 and $9.5 \mathrm{~cm}$ at Sites 1 and 2, respectively (Fig. 2). Zostera marina leaf blade height was positively correlated with water temperature at both sites (Fig. 3). As the growing season progressed and water temperatures increased, leaf blade height increased. The correlations between L. matagordensis populations and Z. marina height were not significant at either Site 1 or Site 2. Zostera marina decreased in density between 02 July 2001 and 04 September 2001. 


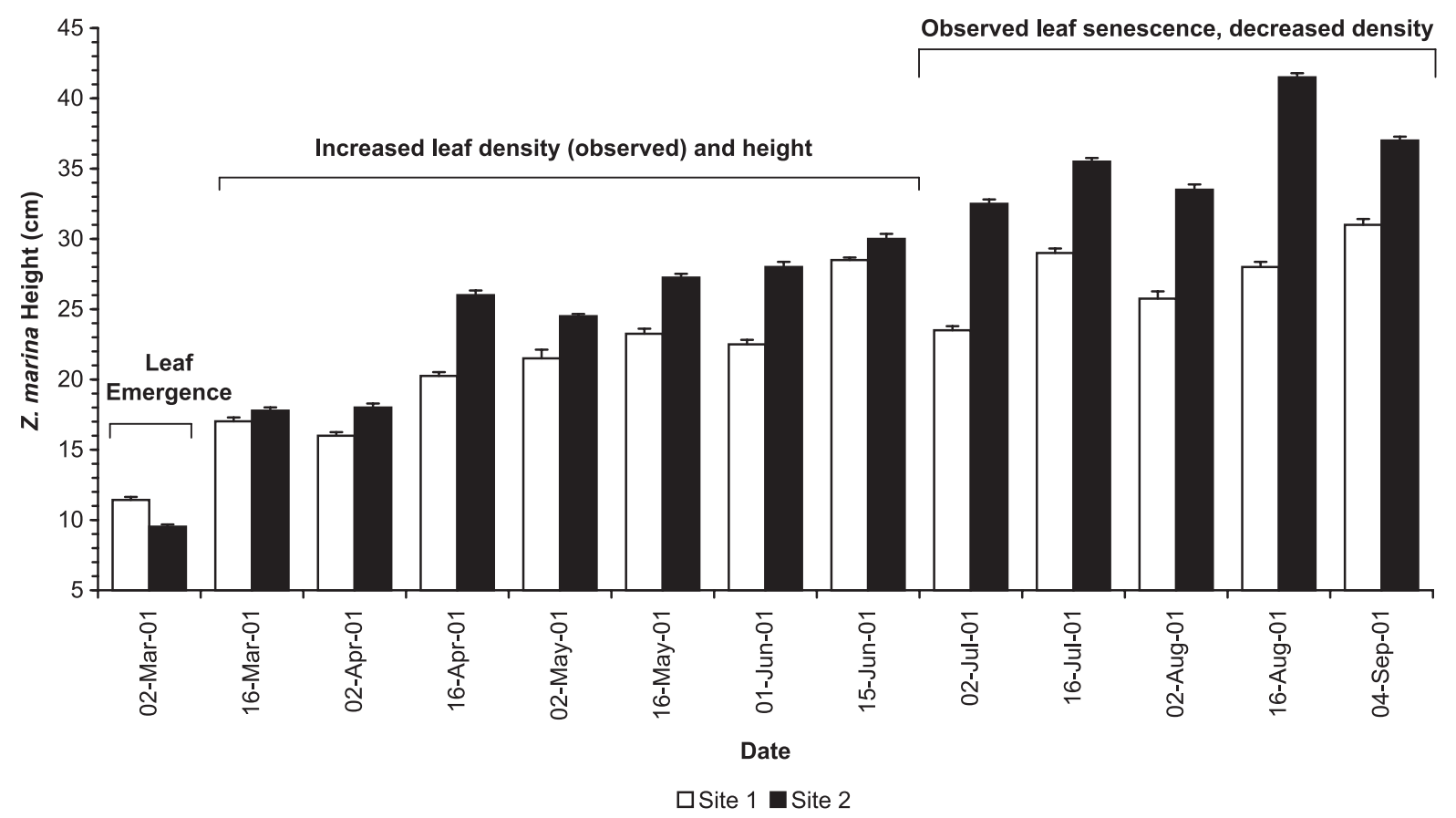

Fig. 2. Seasonal changes in Z. marina height for each collection date at Dameron Marsh Sites 1 and 2.

4.2. Loxoconcha matagordensis breeding cycleDameron Marsh

Loxoconcha matagordensis had two main breeding cycles between March to September 2001, which preceded juvenile population peaks by $\sim 15$ to 30 days; the first breeding cycle was from 01 to 15 June 2001 and the second cycle was from 02 to 16 August 2001 (Fig. 4). The length of time between the breeding cycles was approximately 2 months. The number of

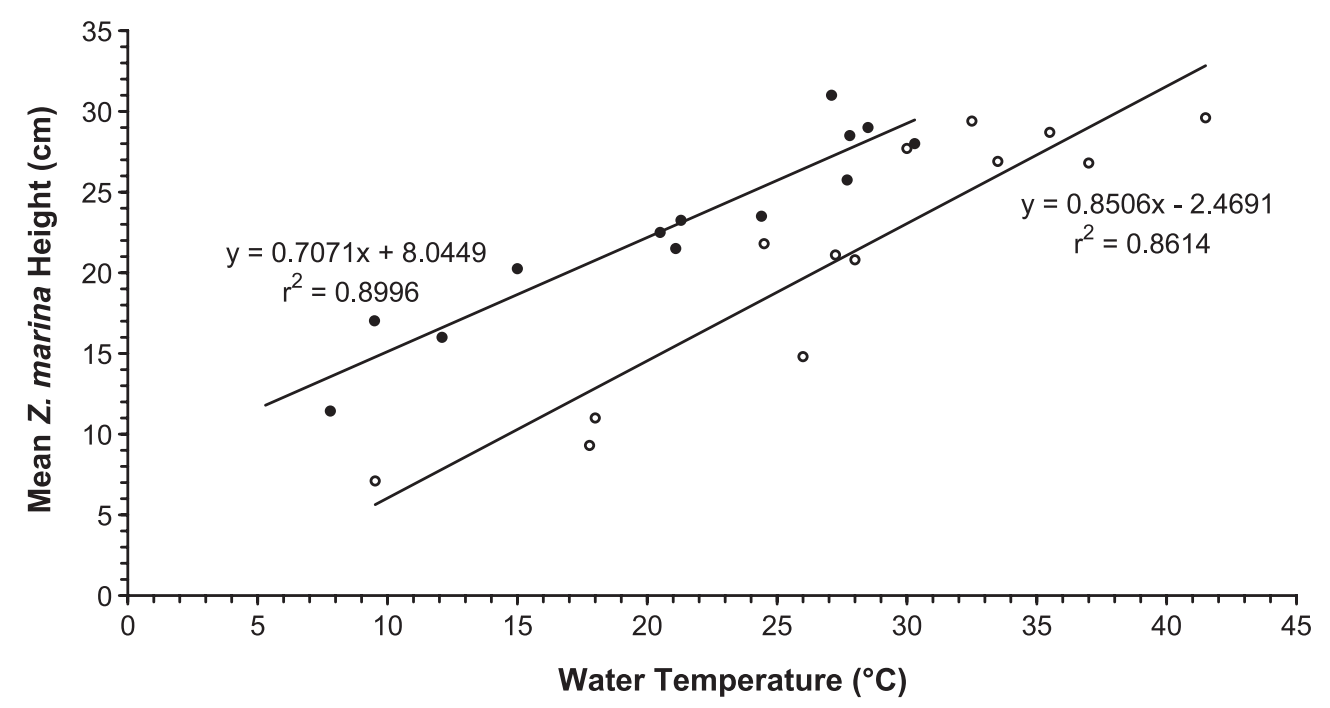

- Site 1 ○ Site 2

Fig. 3. Linear regression analyses of mean Z. marina height versus water temperature for each collection date at Dameron Marsh Sites 1 and 2. 

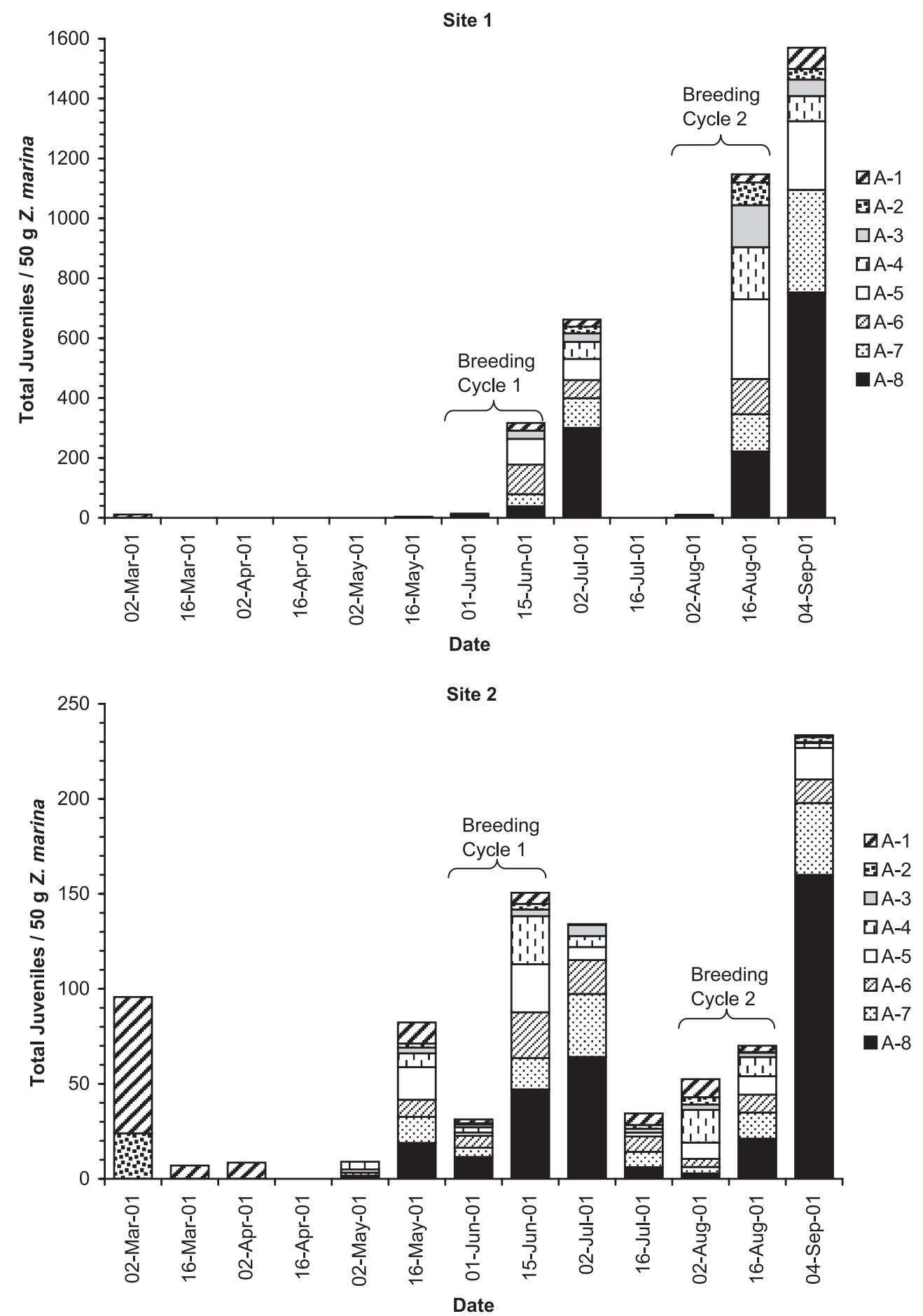

Fig. 4. Seasonal changes in juvenile population structure at Dameron Marsh, Sites 1 and 2. A-1 through A-8 stand for pre-adult molt stages (instars); A-1 is the pre-adult stage. Breeding cycles immediately precede peak total juvenile populations and A-8 instar production. 


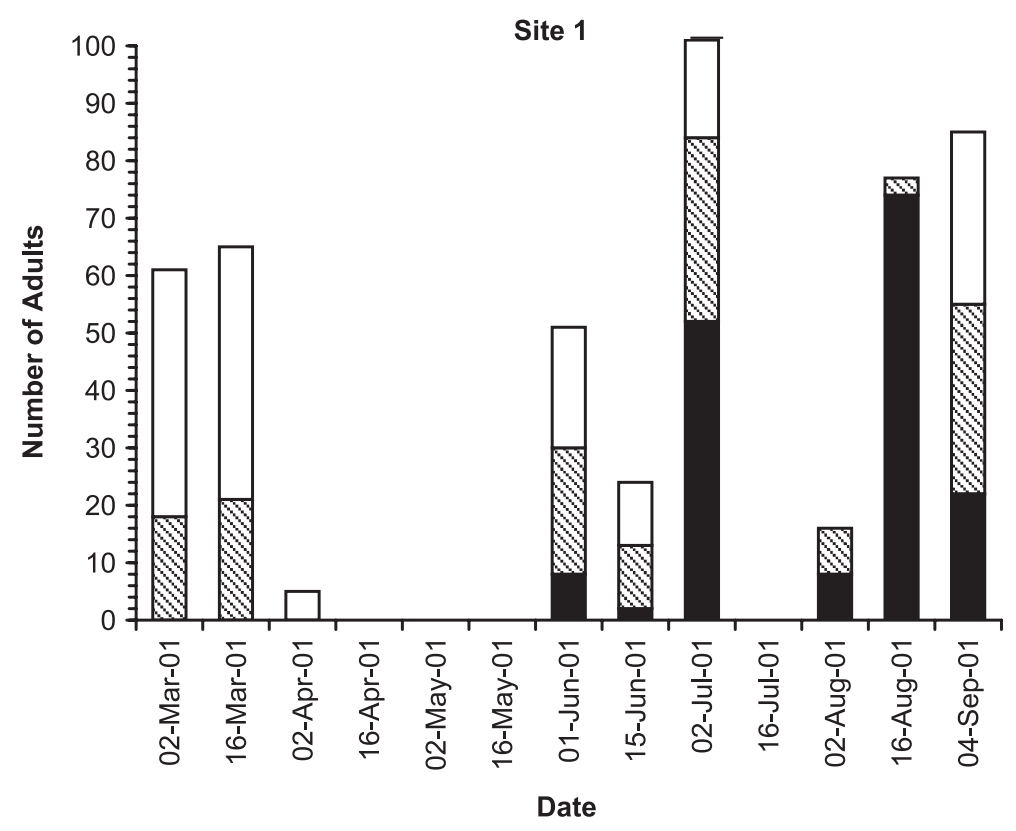

new B Intermediate $\square$ Old

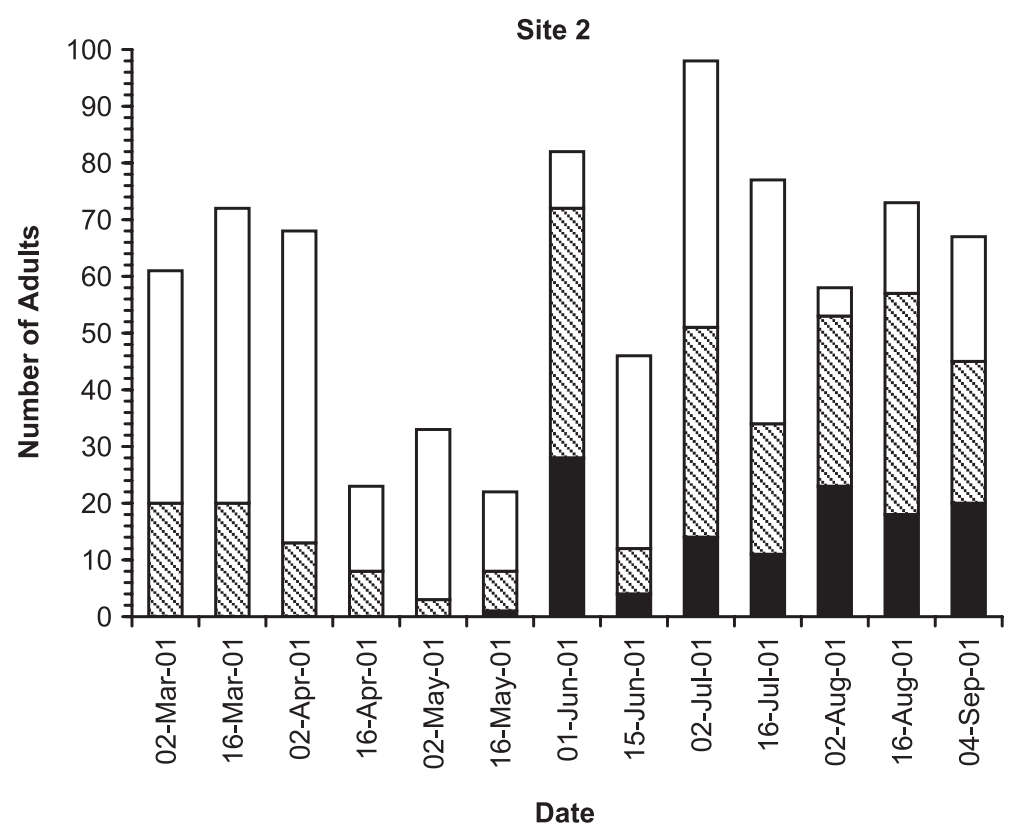

new SIntermediate $\square$ Old

Fig. 5. Seasonal age distribution of adult (male and female) L. matagordensis at Dameron Marsh sites 1 and 2. New=clear translucent shell, Intermediate $=$ transparent brown shell and $\mathrm{Old}=$ opaque dark brown shell. 
juveniles produced increased from June to September with the second cycle producing the largest number of total juvenile (2679) individuals per unit volume of seagrass. In addition, juvenile production closely paralleled increases in water temperature.

Old, dark-brown shelled adults were present between March to April 2001, and most likely represented individuals that over-wintered from the fall of 2000. New, clear-shelled adults did not appear until 16 May to 01 June 2001 (Fig. 5).
Peak populations of new, clear-shelled adults occurred on 01 June, 02 July and 16 August 2001 (Site 1), and 02 August 2001 (Site 2). Female adults accounted for $59 \%$ to $100 \%$ of the total adult population, except for the period between 01 June and 02 July 2001, when females accounted for only $41 \%$ to $58 \%$ of the adult population. The number of males exceeded the number of females by $9 \%$ to $17 \%$ on 01 and 15 June 2001, at Site 1 (Fig. 6).
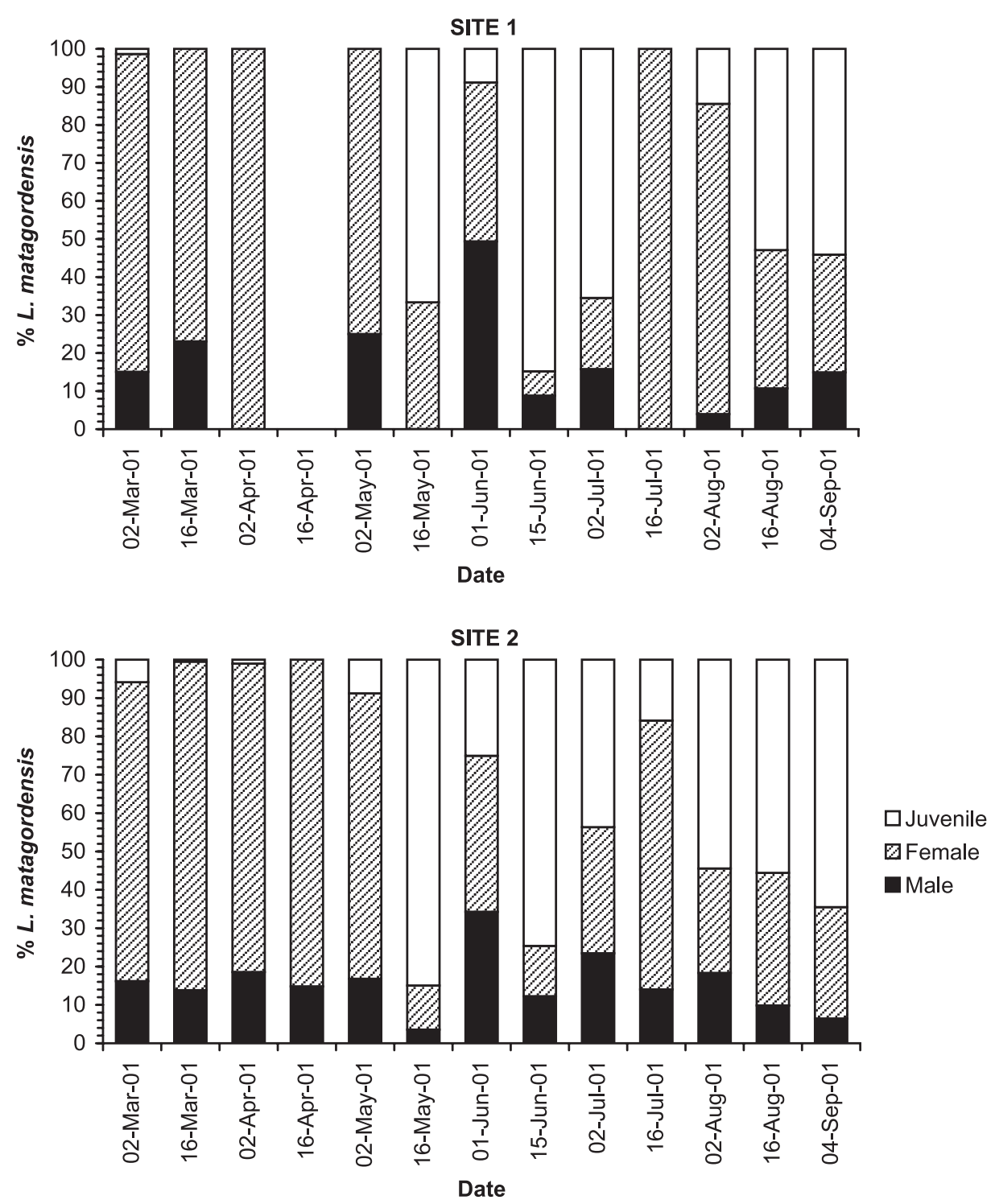

Fig. 6. Seasonal population structure of adults and juveniles for each collection date at Dameron Marsh Sites 1 and 2. 


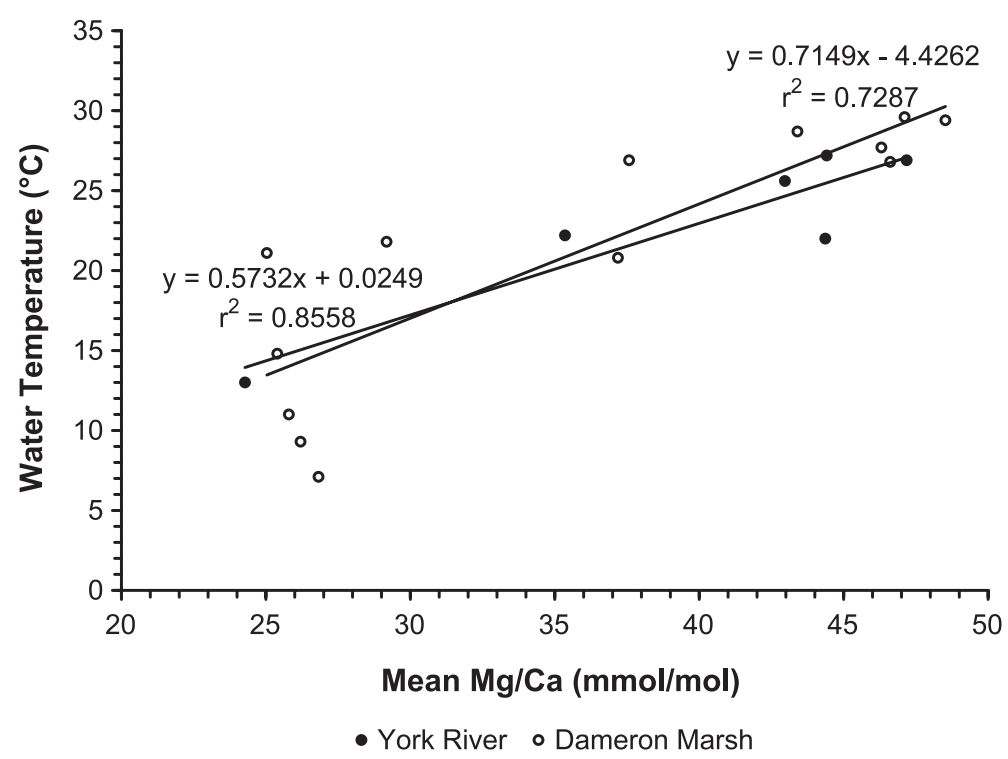

Fig. 7. Linear regression analyses of mean $\mathrm{Mg} / \mathrm{Ca}$ ratios of adult shells versus water temperature at Dameron Marsh, Site 2 and York River.

\subsection{Geochemical Analyses}

$\mathrm{Mg} / \mathrm{Ca}$ and $\mathrm{Sr} / \mathrm{Ca}$ ratios of adult L. matagordensis shells were positively correlated with water temperature at the Dameron Marsh and York River sites (Figs. 7 and 8). At Dameron Marsh, this correlation was strongest between 01 June and 04 September
2001, the time period in which there was a predominance of new to intermediate aged L. matagordensis (Figs. 9 and 10). $\mathrm{Mg} / \mathrm{Ca}$ ratios of old shells collected from 03 March and 01 June 2001, were not correlated with water temperature and $\mathrm{Sr} / \mathrm{Ca}$ correlations were lower. Old L. matagordensis shells collected from Dameron Marsh on 01 and 16 June

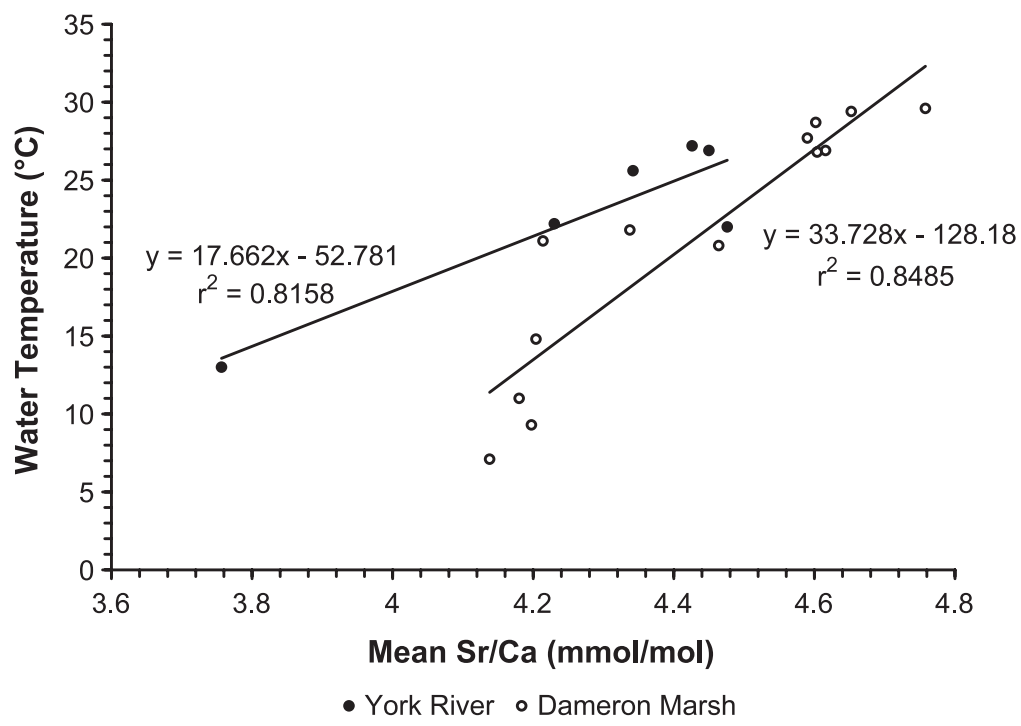

Fig. 8. Linear regression analyses of mean $\mathrm{Sr} / \mathrm{Ca}$ ratios of adult shells versus water temperature at Dameron Marsh, Site 2 and York River. 

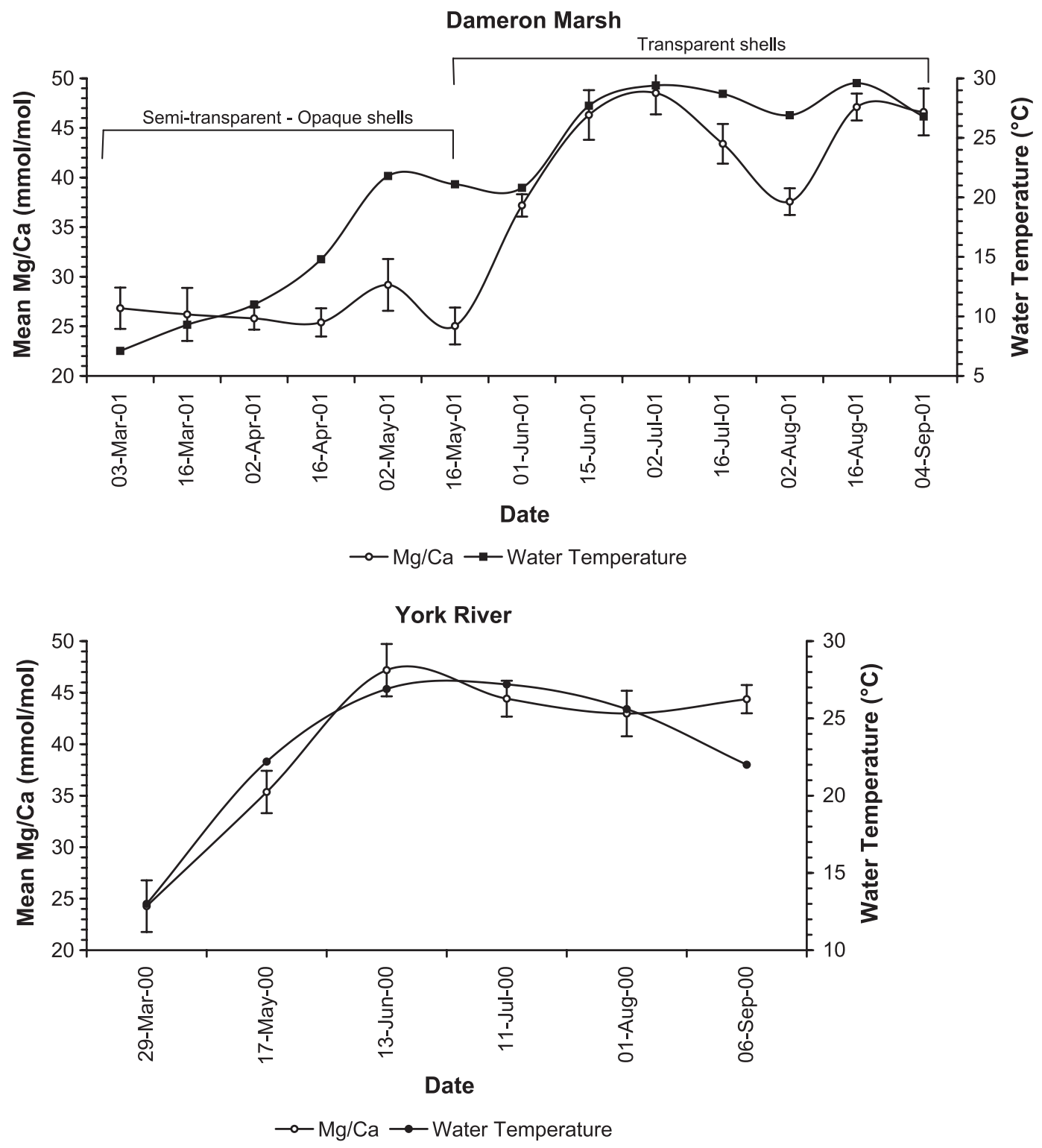

Fig. 9. Relationship between mean $\mathrm{Mg} / \mathrm{Ca}$ ratios of adult shells and water temperature for each collection date at Dameron Marsh, Site 2 and York River. Semi-transparent-opaque shells that wintered-over from the previous season are less correlated with water temperature than newly secreted transparent shells at Dameron Marsh, Site 2.

2001, contained $10 \%$ to $23 \%$ and $1 \%$ to $6 \%$ less $\mathrm{Mg} /$ $\mathrm{Ca}$ and $\mathrm{Sr} / \mathrm{Ca}$, respectively, than newly secreted shells.

Shell $\mathrm{Mg} / \mathrm{Ca}$ ratios were positively correlated with $\mathrm{Sr} / \mathrm{Ca}$ ratios at both Dameron Marsh and York River (Fig. 11), however, water salinity showed no apparent correlation with $\mathrm{Mg} / \mathrm{Ca}$ or $\mathrm{Sr} / \mathrm{Ca}$ ratios at either site.
In contrast to the living L. matagordensis, fossil shells of Loxoconcha sp. A from three Chesapeake Bay sediment cores showed weak correlations between $\mathrm{Mg} / \mathrm{Ca}$ and $\mathrm{Sr} / \mathrm{Ca}$ ratios from the same shells (Fig. 12a). Moreover, both $\mathrm{Mg} / \mathrm{Ca}$ and $\mathrm{Sr} / \mathrm{Ca}$ ratios are generally lower for Loxoconcha $\mathrm{sp}$. A than those for L. matagordensis. However, there are 

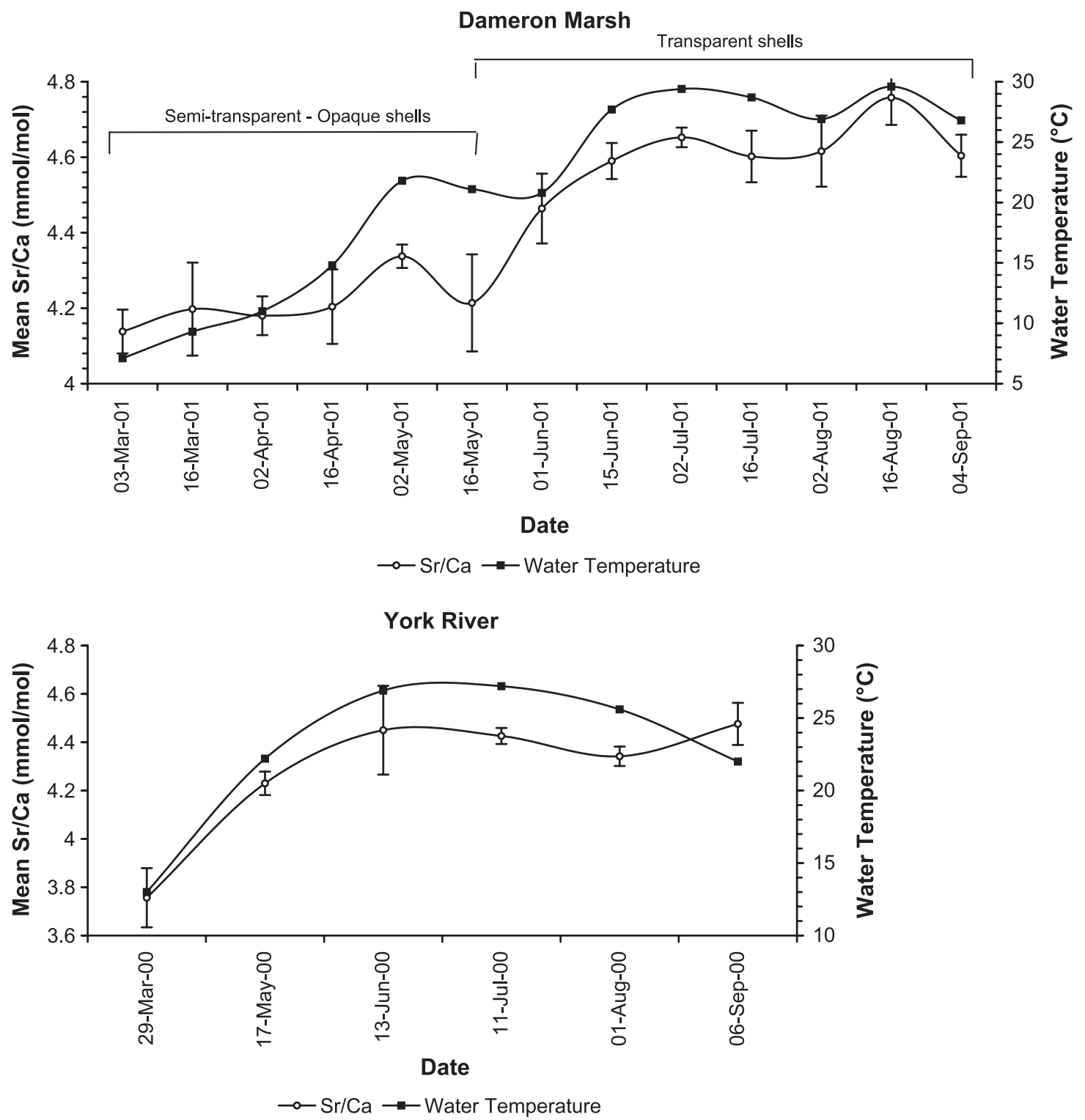

Fig. 10. Relationship between mean $\mathrm{Sr} / \mathrm{Ca}$ ratios of adult shells and water temperature for each collection date at Dameron Marsh, Site 2 and York River. Semi-transparent-opaque shells that wintered-over from the previous season are less correlated with water temperature than newly secreted transparent shells at Dameron Marsh, Site 2.

notable periods of low $\mathrm{Mg} / \mathrm{Ca}$ and $\mathrm{Sr} / \mathrm{Ca}$ ratios in core PTXT-2-P-5 ( 1530-1550, 1680, 1780-1810, $1840 \mathrm{AD})$ and core RD-K-98 ( 1750, 1790, 1840 1850 AD) (Fig. 12b), which seem to signify cool regional conditions during parts of the Little Ice Age (Cronin et al., 2003).

\section{Discussion and conclusions}

This is the first study to investigate breeding cycles, population structure and shell chemistry of Loxoconcha in a natural estuarine environment. In this study, we determined that two breeding cycles 


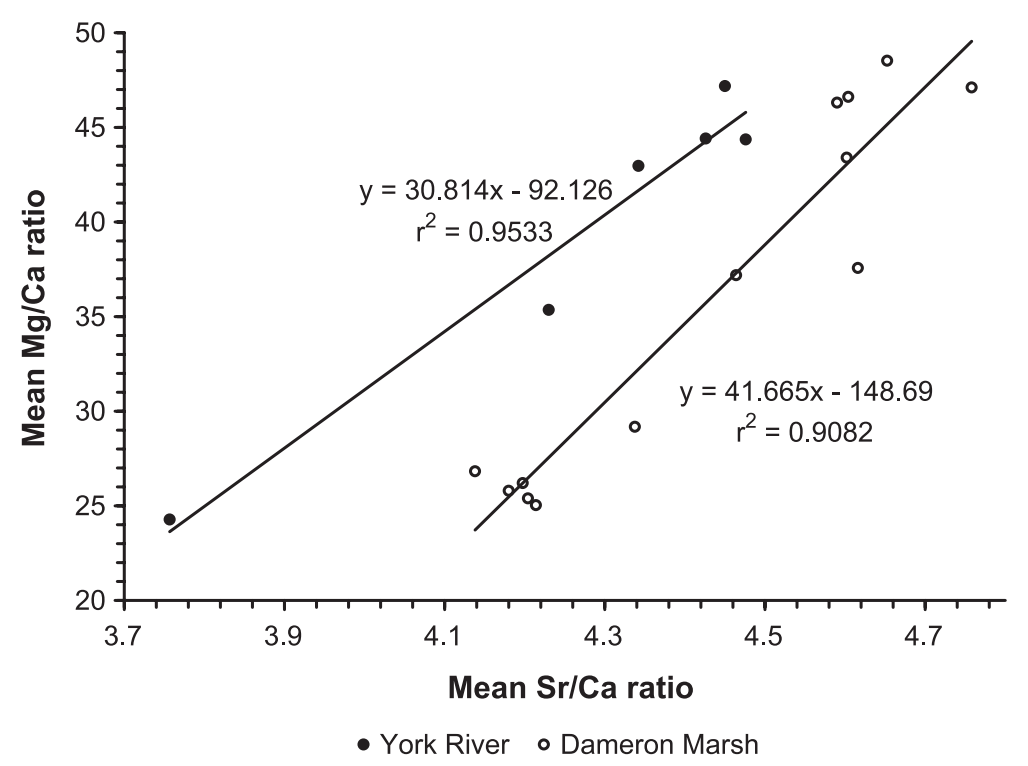

Fig. 11. Linear regression analyses of mean $\mathrm{Sr} / \mathrm{Ca}$ versus mean $\mathrm{Mg} / \mathrm{Ca}$ ratios at Dameron Marsh, Site 2 and York River.

occurred between March and September 2001 at Dameron Marsh. Each breeding cycle produced a progressively greater number of juveniles, with the largest numbers produced from the second breeding cycle in August 2001. This late season increase in production is most likely a survival strategy that ensures continued existence from one season to another and from year to year.

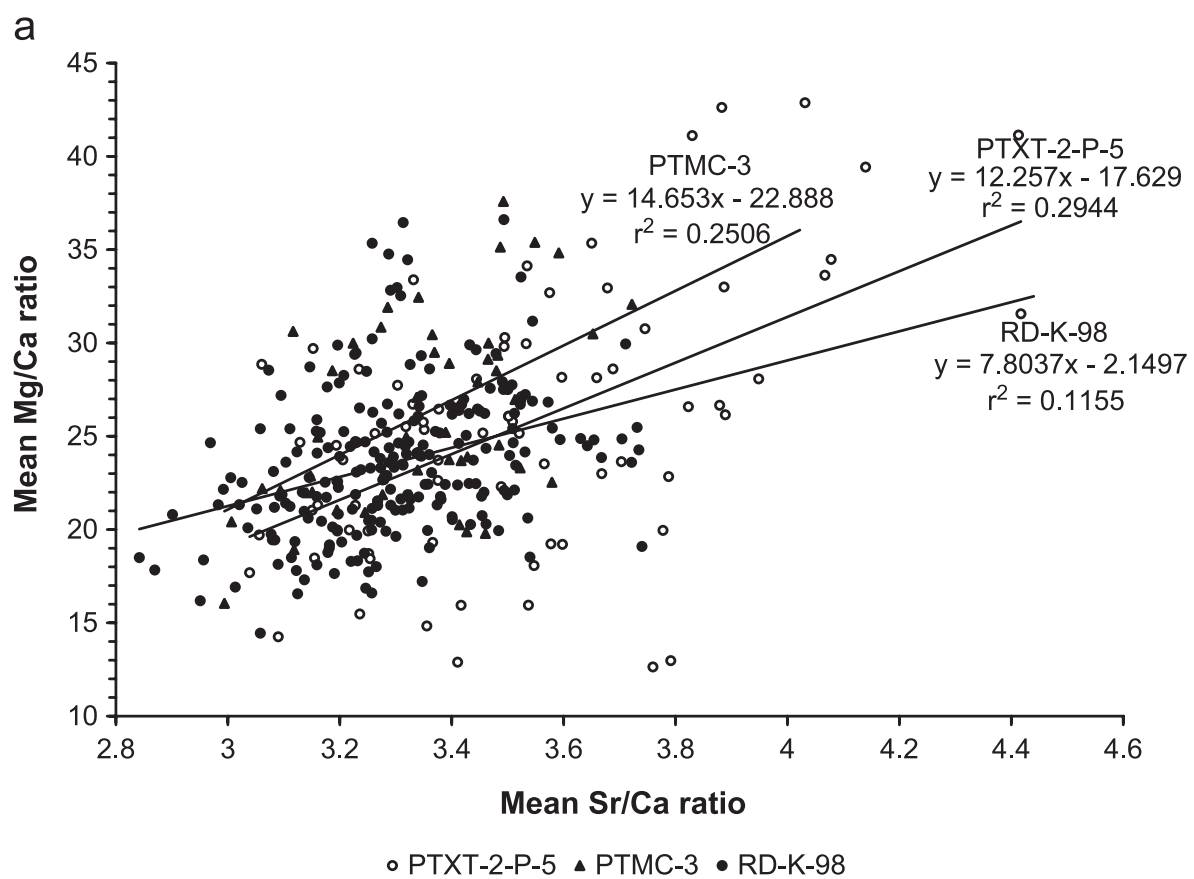

Fig. 12. (a) Regressions of $\mathrm{Sr} / \mathrm{Ca}$ and $\mathrm{Mg} / \mathrm{Ca}$ ratios of fossil shells of Loxoconcha sp. A from sediment cores RD-K-98/MD99-2209, PTXT-2-P5 and PTMC-3, from the Chesapeake Bay. (b) Same downcore $\mathrm{Sr} / \mathrm{Ca}$ and $\mathrm{Mg} / \mathrm{Ca}$ data plotted against age (see Cronin et al. 2003 for age data). 
b

PTXT-2
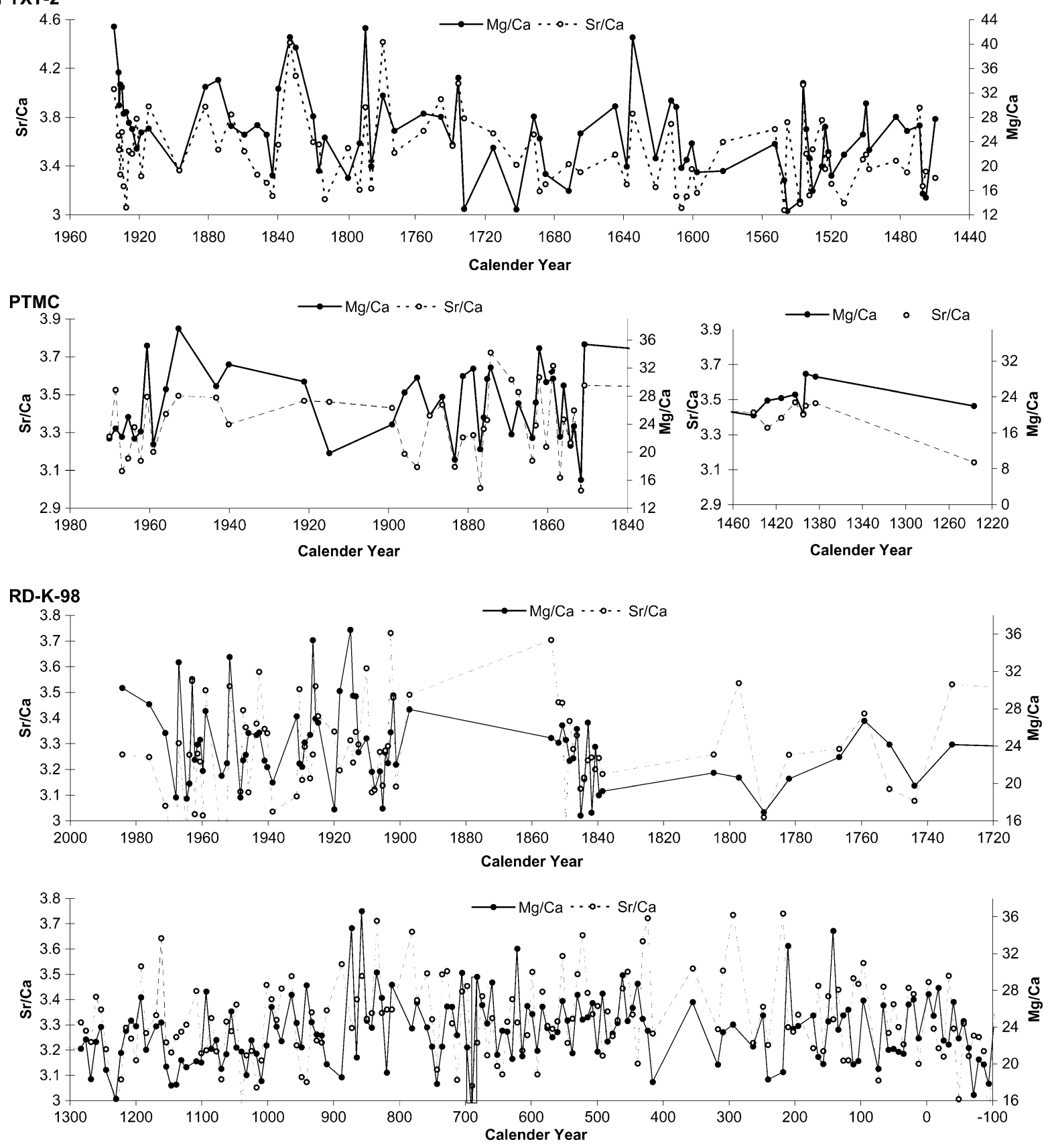

Fig. 12 (continued).

Because water temperature affects several physiological processes in ostracodes, it is most likely a major factor that influences the time of breeding.
Theisen (1966) showed that a minimum water temperature of 8 to $12{ }^{\circ} \mathrm{C}$ was required for egg development in the brackish-water species, Loxocon- 
cha elliptica (Brady). In addition, water temperature acts as a secondary regulator in the molt cycle of all crustaceans (Aiken and Waddy, 1992; Skinner, 1985). A culture study of the ostracode Krithe praetexta praetexta showed that warmer temperatures $\left(14{ }^{\circ} \mathrm{C}\right)$ resulted in more rapid ontogenetic development than cooler temperatures $\left(5\right.$ and $\left.10{ }^{\circ} \mathrm{C}\right)$ (Majoran et al., 2000).

Breeding time may also be influenced by the seasonal growth characteristics of the seagrass $Z$. marina. Our results show that $Z$. marina height is strongly correlated with water temperature at both study sites, and that leaf senescence begins in midJune resulting in a progressive decrease in habitat density through 04 September 2001. When the habitat decreases to a certain point, the second breeding cycle is likely initiated. Thus, water temperature may indirectly regulate L. matagordensis breeding time by affecting the habitat on which it lives.

Water salinity did not affect breeding time in this experiment. Salinity levels declined between 03 March 2001 and 02 July 2001 at both Dameron Marsh sites due to above normal precipitation during this period (Fig. 13). This salinity decline and the
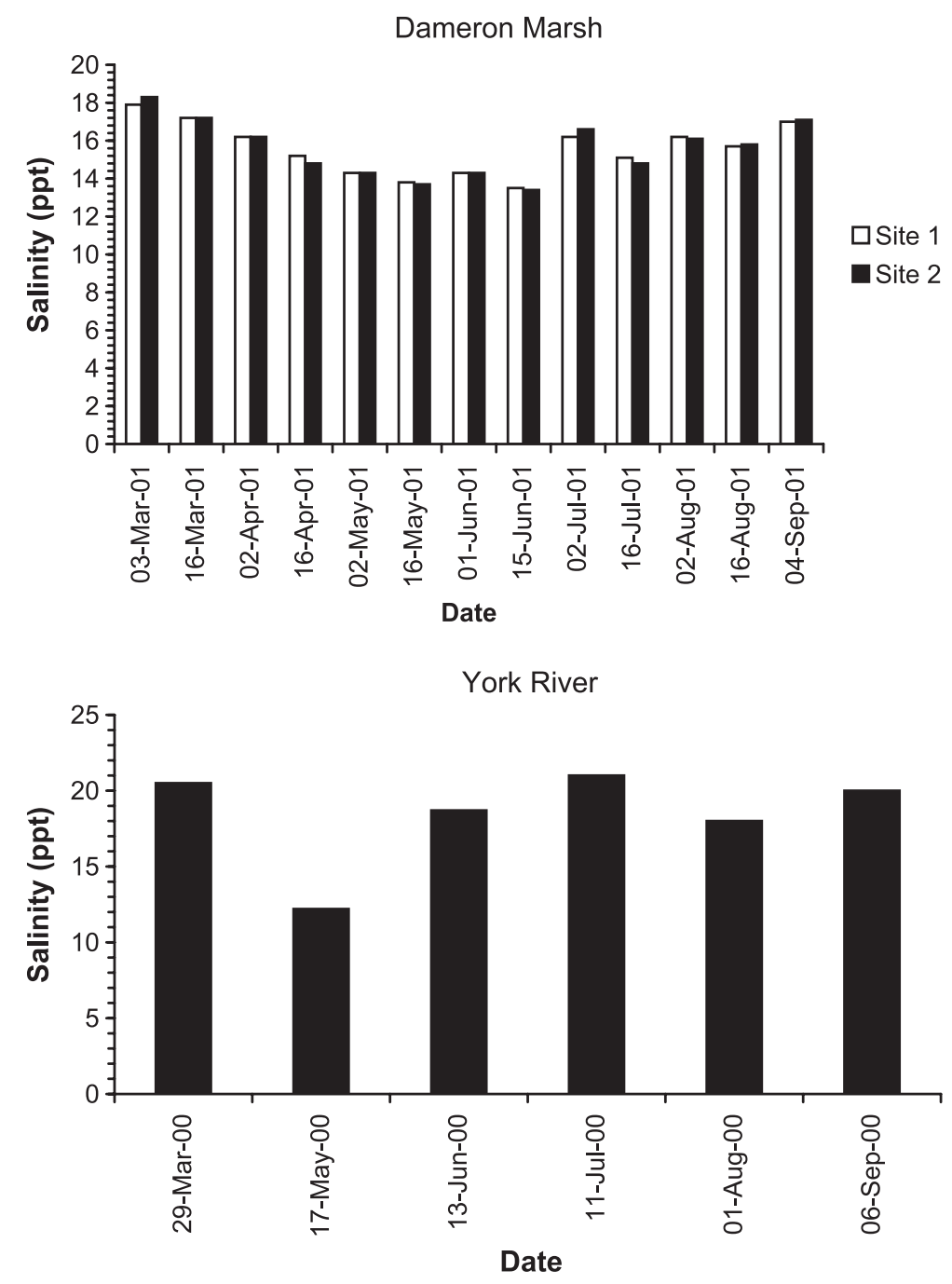

Fig. 13. Water salinity levels at Dameron Marsh and York River. 
small amount of variance in salinity levels, $4.3 \mathrm{ppt}$, over the course of the experiment showed no relationship with the time of breeding.

Although two breeding cycles were apparent, there was continuous juvenile production from May to September 2001, especially at Dameron Marsh Site 2. Juvenile production was $53 \%$ to $100 \%$ lower at intermittent times than directly after peak breeding cycles. This continued production after peak breeding most likely occurred as a result of instars being discharged over a period of time, instead of all at once. In a culturing study of Xestolebris hanaii Ishizaki, Ikeya and Kato (2000) found that the order in which the eggs were laid determined the time of hatching; eggs laid first, hatched first. Xestoleberis hanaii Ishizaki instars were subsequently released at a rate of two to three per day from the adult carapace and total discharge of all instars took ten to fifteen days (Ikeya and Kato, 2000).

Continuous calcification of new adult shells throughout the breeding season introduces variability when using minor element analyses of adult shells for paleoenvironmental reconstruction. Although $\mathrm{Sr} /$ $\mathrm{Ca}$ and $\mathrm{Mg} / \mathrm{Ca}$ ratios can vary by as much as $6 \%$ to $23 \%$, respectively, between new and old shells, our results indicate that water temperature is strongly correlated with both $\mathrm{Sr} / \mathrm{Ca}$ and $\mathrm{Mg} / \mathrm{Ca}$ ratios between March and September. These results are consistent with several previous studies that have suggested water temperature as a dominant factor controlling $\mathrm{Mg} / \mathrm{Ca}$ ratios in ostracode shells (Chivas et al., 1983; Engstrom and Nelson, 1991; De Deckker et al., 1999).

The incorporation of $\mathrm{Sr}$ into the shell, however, is more complex and poorly understood. Some studies have suggested that $\mathrm{Sr}$ uptake is regulated by water chemistry, specifically the $\mathrm{Sr} / \mathrm{Ca}$ ratio and salinity of the host water, and is independent of temperature (Chivas et al., 1993). In contrast, Xia et al. (1997) reports a strong positive covariance between $\mathrm{Mg} / \mathrm{Ca}$ and $\mathrm{Sr} / \mathrm{Ca}$ ratios of the lacustrine ostracode C. rawsoni, suggesting that the $\mathrm{Mg}$ content of the shell directly affects $\mathrm{Sr}$ uptake by either crystallography (as the shell $\mathrm{Mg}$ content increases, the calcite structure becomes more distorted thereby allowing for greater $\mathrm{Sr}$ uptake) or, possibly, because of the large amount of physio- logical energy required to exclude $\mathrm{Mg}$ and/or $\mathrm{Sr}$ during calcification. If the shell $\mathrm{Mg} / \mathrm{Ca}$ ratio is primarily regulated by water temperature as suggested, this $\mathrm{Mg} / \mathrm{Ca}-\mathrm{Sr} / \mathrm{Ca}$ correlation would indicate that seasonal variability in shell $\mathrm{Sr} / \mathrm{Ca}$ ratios is an indirect result of fluctuating water temperatures (Xia et al., 1997). In this study, water salinity varied within a range of only 4.9 and 8.3 ppt between March and September at Dameron Marsh and York River, respectively (Fig. 13), and salinity was not correlated with shell $\mathrm{Sr} / \mathrm{Ca}$ ratios. In addition, shell $\mathrm{Sr} / \mathrm{Ca}$ ratios were strongly correlated with water temperature for Dameron Marsh and York River and with shell $\mathrm{Mg} / \mathrm{Ca}$ ratios for Dameron Marsh and York River. These results suggest that the seasonal variability in shell $\mathrm{Sr} / \mathrm{Ca}$ ratios may be indirectly regulated by changes in water temperature.

In contrast to this study, a strong positive correlation between shell $\mathrm{Sr} / \mathrm{Ca}$ and $\mathrm{Mg} / \mathrm{Ca}$ was absent (Dwyer et al., 2002) in laboratory culturing experiments on L. matagordensis, perhaps due to weak calcification or other unnatural environmental factors in the cultures. A positive correlation between $\mathrm{Mg} / \mathrm{Ca}$ and $\mathrm{Sr} / \mathrm{Ca}$ was also absent in sub-tropical Florida Bay populations of Loxoconcha (Dwyer and Cronin, 2001) and in the deep-sea ostracode genus Krithe (Cronin et al., 1996). Because $\mathrm{Sr} / \mathrm{Ca}$ ratios increase with precipitation rate in inorganic calcite (Morse and Mackenzie, 1990), our study suggests that L. matagordensis populations from temperate regions like Chesapeake Bay may behave in a similar fashion and precipitate their shells more rapidly in warmer water than in colder water, leading to the apparent temperature- $\mathrm{Sr} / \mathrm{Ca}$ relationship. In other words, temperature variation in the Chesapeake Bay may be sufficiently large to affect calcification rates, and thereby lead to the observed $\mathrm{Mg} / \mathrm{Ca}: \mathrm{Sr} / \mathrm{Ca}$ covariation. The lack of an obvious correlation between $\mathrm{Mg} / \mathrm{Ca}$ and $\mathrm{Sr} / \mathrm{Ca}$ ratios in the fossil Loxoconcha sp. A may indicate "vital' effects between the two species in terms of $\mathrm{Sr}$ substitution during calcification, different seasonal ecology, or unknown hydrological factors.

\section{Acknowledgements}

We thank Drs. K. Moore, R. Orth and B. BerryNiekirk and their staff at the Virginia Institute of 
Marine Science for the collection of York River seagrass samples. We are grateful to J. Damon, C. Nytch, A. Lavenburg and D. Korejwo for their assistance in the collection of seagrass at Dameron Marsh. Drs. B. Wardlaw and J. Self-Trail kindly provided useful reviews of the manuscript.

\section{References}

Aiken, D.E., Waddy, S.L., 1992. The growth process in crayfish. Review of Aquatic Science 6, 362-371.

Chivas, A.R., De Deckker, P., Shelley, J.M.G., 1983. Magnesium, strontium and barium partitioning in non-marine ostracode shells and their use in paleoenvironmental reconstructions-a preliminary study. In: Maddocks, R.F. (Ed.), Applications of Ostracoda. University of Houston, pp. 238-249.

Chivas, A.R., De Deckker, P., Shelley, J.M.G., 1986. Magnesium and strontium in non-marine ostracod shells as indicators of paleosalinity and paleotemperature. Hydrobiologia 143, 135-142.

Chivas, A.R., De Deckker, P., Cali, J.A., Chapman, A., Kiss, E., Shelley, J.M.G., 1993. Coupled stable-isotope and minorelement measurements of lacustrine carbonates as paleoclimatic indicators. In: Swart, P.K. (Ed.), Climate Change in Continental Isotopic Records. AGU, pp. 113-122.

Corrège, T., De Deckker, P., 1997. Faunal and geochemical evidence for change in intermediate water temperature and salinity in the western Coral Sea during the Late Quaternary. Palaeogeography, Palaeoclimatology, Palaeoecology 131, 183-205.

Cronin, T.M., Dwyer, G.S., Baker, P.A., Rodriguez-Lazaro, J., Briggs Jr., W.M., 1996. Deep-sea Ostracode shell chemistry (Mg:Ca ratios) and Late Quaternary Artic Ocean history. In: Austin, J.T., Bergsten, W.E.N., Jennings, A.E. (Eds.), Late Quaternary Palaeoceanography of the North Atlantic Margins, vol. 111. Geological Society Special Publication, pp. 117-134.

Cronin, T.M., Dwyer, G.S., Kamiya, T., Schwede, S., Willard, D.A., 2003. Medieval warm period, little ice age and 20th century temperature variability from Chesapeake Bay. Global and Planetary Change 36, 17-29.

Cronin, T.M., Kamiya, T., Dwyer, G.S., Vann, C.D., Schwede, S., Wagner, R., Belkin, H., in press. Ecology and shell chemistry of Loxoconcha matagordensis. Palaeogeography, Palaeoclimatology, Palaeoecology.

De Deckker, P., Chivas, A.R., Valveey, J.M.G., 1999. Uptake of Mg and $\mathrm{Sr}$ in the euryhaline ostracod Cyprideis determined from in vitro experiments. Palaeogeography, Palaeoclimatology, Palaeoecology $148,105-116$.

Dwyer, G.S., Cronin, T.M., 2001. Ostracode shell chemistry as a paleosalinity proxy in Florida Bay. In: Wardlaw, B. (Ed.), Bulletins of American Paleontology, vol. 361, pp. 249-276.

Dwyer, G.S., Cronin, T.M., Baker, P.A., Raymo, M.E., Buzas, J.S., Corrège, T., 1995. North Atlantic deep-water temperature change during late Pliocene and late Quaternary climatic cycles: new insight from ostracode shell chemistry. Science 270, $1347-1351$.

Dwyer, G.S., Cronin, T.M., Baker, P.A., 2002. Trace elements in marine ostracodes. In: Holmes, J.A., Chivas, A.R. (Eds.), American geophysical union monograph, vol. 131, pp. 205-225.

Engstrom, D.R., Nelson, S.R., 1991. Paleosalinity from trace metals in fossil ostracodes compared with observational records at Devils Lake, North Dakota, USA. Palaeogeography, Palaeoclimatology, Palaeoecology 83, 295-312.

Ikeya, N., Kato, M., 2000. The life history and culturing of Xestrolebris hanaii (Crustacea Ostracoda). Hydrobiologia 419, $149-159$.

Ito, E., De Deckker, P., Eggins, S.M., 2003. Ostracodes and their shell chemistry: implications for paleohydrologica and paleoclimatic applications. In: Park, L.E., Smith, A.J. (Eds.), Bridging the gap: trends in the ostracode biological and geological sciences, The Paleontological Society papers, vol. 9, pp. 119-151.

Kamiya, T., 1988. Contrasting population ecology of two species of Loxoconcha (Ostracoda, Crustacea) in recent Zostera (eelgrass) beds: adaptive differences between phytal and bottom-dwelling species. Micropaleontology 34, 316-331.

Majoran, S., Agrenius, S., Kucera, M., 2000. The effect of temperature on shell size and growth rate in Krithe praetextra praetextra (Sars). Hydrobiologia 419, 141-148.

Morse, J.W., Mackenzie, F.F., 1990. Geochemistry of sedimentary carbonates. Elsevier, Amsterdam. 696 pp.

Palacios-Fest, M.R., Dettman, D.L., 2001. Temperature controls monthly variation in ostracode valve $\mathrm{Mg} / \mathrm{Ca}$ : Cypridopsis vidua from a small lake in Sonora, Mexico. Geochimica et Cosmochimica Acta 65, 2499-2507.

Roca, J.R., Wansard, G., 1997. Temperature influence on development and calcification of Herpetocypris brevicaudata Kaufmann, 1900 (Crustacea: Ostracoda) under experimental conditions. Hydrobiologia 347, 91-95.

Skinner, M.D., 1985. Molting and regeneration. In: Bliss, D.E., Mantel, L.H. (Eds.), The Biology of Crustacea. Academic Press, pp. $44-128$.

Swain, F.M., 1955. Ostracoda of San Antonio Bay, Texas. Journal of Paleontology 29, 561-646.

Theisen, B.F., 1966. The life history of seven species of ostracods from a Danish brackish-water locality. Meddelelser fra Danmarks Fiskeri-og Havundersøgelser 4, 215-270.

Turpen, J.B., Angell, R.W., 1971. Aspects of moulting and calcification in the ostracod Heterocypris. Biological Bulletin (Woods Hole, Mass.) 140, 331-338.

Wansard, G., De Deckker, P., Julià, R., 1998. Variability in ostracod partition coefficients $\mathrm{D}(\mathrm{Sr})$ and $\mathrm{D}(\mathrm{Mg})$. Implications for lacustrine palaeoenvironmental reconstruction. Chemical Geology 146, 39-54.

Xia, J., Engstrom, D.R., Ito, E., 1997. Geochemistry of ostracode calcite: Part 2. The effects of water chemistry and seasonal temperature variation on Candona rawsoni. Geochimica et Cosmochimica Acta 61, 383-391. 